\title{
New Trend in Vegetable Production: Tomatillo
}

\author{
Polat Serdar ${ }^{1 *}$ and HanGamze ${ }^{2}$ \\ ${ }^{1}$ Department of Horticulture, Namık Kemal University, Turkey \\ ${ }^{2}$ Departmen of Food Engineering, Namık Kemal University, Turkey
}

Submission: February 15, 2018; Published: March 13, 2018

"Corresponding author: Polat Serdar, Department of Horticulture, Agricultural Faculty, Namık Kemal University, Turkey, Tel: 00902822502062; Email: spolat@nku.edu.tr

\begin{abstract}
The present study was conducted to evaluate the germination percentage of the tomatillo seeds and physico-chemical properties of tomatillos at the Horticultural and food chemical Lab of Agricultural Faculty. The titrable acidity was $12,30 \mathrm{~g} / \mathrm{l}$, pH was 3,87 and average weight without husk was $11,59 \mathrm{~g} /$ berry. Diameter and lenght were measured as $2,74 \mathrm{~cm}$ and $2,09 \mathrm{~cm}$ respectively. The germination percent was found $25 \%$ due to the in insufficient maturation. Pectin content was measured 0,82gram/10 gram. This study reveals that tomatillocan be grown in the northwest part of the Turkey (Marmara region, Trace region) and can be consume as fresh and dry fruit or by-products in food industry such as marmelade, pickle, sauce.
\end{abstract}

Keywords: Tomatillo; Physalis ixocarpa; Wild species; Vegetable; Phytoremidetion

\section{Introduction}

Tomatillo is belong to Solanaceae family like tomato, potato and tobacco. Physalis is a Greek word inferred to 'bladder-pouch' which refers to swollen flowers [1]. The name of tomatillo, Physalis ixocarpa Brot. become known in English tomatilo, husk tomato, jambeey, in Spanish; tomate de cascara, tomate de fresadilla, in Mexico; tomate milpero, tomate verde, tomatillo and Guatemala; miltomate [2]. From ancient times it has become a vegetable spreading from the South of the United States to Mexio-Guatemala and tomatillo lead the way the indigenous communities in there called Mesoamericans, have built up their livelihood based on agriculture [2]. Particularly, 78\% of 90 Physalis species grow in Mexico in wide scope the from North America to Argentina [3]. During to the improvement of technology and industry, the agricultural sector has also developed, tomatillo taking its place cost-efficient and a manufactured product [4]. Tomatillo has the potential to become a commercial exotic vegetable that attracts attention in the food industry all over the World. Tomatillos are valuable products that exported to from several countries such as Colombia, Egypt, Zimbabwe, Kenya, Madagascar, South Africa and Asia to around the World. Among these countries, it is the most produced, consumed and exported vegetable (2nd rank of 15 vegetables or fruits) in Colombia [5,6].

The ash content of tomatillo is 7,3-7,8\%. Tomatillos has less iron content and higher sodium level than tomatoes and also is rich in magnesium [7]. Organic acid composition in tomatillo is high based citric acid while it contains more organic acid than fresh and cooked tomatoes [8]. Tomatillos contain $7 \%$ reduced sugar. In their fresh consumption, they contain less fructose and more glucose and sucrose than tomatoes. With cooked forms, fructose and sucrose increase while glucose decreases. In case of cooked tomatillo ensamples, the amount of glucose is less than that of cooked tomatoes and the quantity of sucrose is higher than that of cooked tomatoes, sucrose degree is higher and the fructose values are the equal [8]. Tomatillo comprise deconoic acid and 3 times more fatty acid. In cooked tomatillos, it was observed that the amount of linoleic acid enhanced and deconoic acid decreased. The presence of polyunsaturated fatty acid preserves the public health and diminishes the risk of cardiovascular dieases $[8,9]$.

The total of pectin which is obtained from tomatillo (EA:13,9$18,3 \mathrm{~kJ} / \mathrm{mol}$ ) is less than blackcurrant/apple (EA:32-39kJ/mol) and ad orange (EA:25kJ/mol) though, due to the activation energies of pectin formation, it is more qualified than others. In addition, the pectin of tomatillo was found having higher fragility than citrus by penetration test. Therefore, using of tomatillo origin pectins in food formulations has high potential [1012]. A total of 52 volatile components were identified in fresh tomatillos, 22 items which were tomatillo includes; hydroxy esters, aromatic esters, decanoic acid and terpens specifically. These phenols have antioxidant and antiseptic properties 
[8]. Furthermore, ixocarpalactones A ve B, ixacarpanolide, dihidrowithanolideD, with a physacarpin, philadelphicalactones A and B, 18-hydroxywithanolide D, 2,3 dihydroixocarpalactone B, $4 \beta, \quad 7 \beta, 20$ R-trihydroxy-1-oxowitha-,5-dien-22,26-olide ve physalin B are isolated from Physalis (tomatillo) plant. These carcinogenic structures may be used in the pharmaceutical industry [13].

Tomatillo is high resistant to viruses and pesticides due to the special glandular structure in its leaves. Many species of physalis are thought to be well tolerated against viral diseases $[14,15]$. It is believed by inhabitant in Mexico, that the high lysosomal activity in the pod (based on 45/100-egg white is 100 degree) with some of the sticky sucrose esters surrounding the fruit protect tomatillo from insects and fungi [16].

Tomatillo has a flower structure of 5 ( 5 sepals and 5 petals). When the leaves are adjacent to each other and green, the petals are bright yellow. The characteristic of tomatillo is the intense growth of the flowers, after the focantancy of the bear, the fruit envelope during flower development [15]. Tomatillo is a climacteric fruit with under specified temperature and humdity conditions $\left(+5{ }^{\circ} \mathrm{C}\right.$ ve $\left.75-80 \%\right)$ to retain an acceptable level of quality attributes [17].

\section{Discussion}

In general, tomatillos consume freshly and they are used in soups, sauces and particulary green sauces which are typical for Mexican and Guatemalan cusines. Mexican green sauce called 'Enchials verde' exhaust with chips. Another method of evaluation is making jam or canning [18]. In addition to its general use, tomatillo has also started to be used in trending fusion cooking currents. Leaves surrounding tomatillos are used amateurly to improve the rheological properties of dough in bakery products and to enrich with rice flavor. The investigate of tomatillo and its plant for their compatibility with other basic products in the food sector will also contribute greatly to the formation of new gastromomic tastes. From unexplored parts of tomatillo; It is essential to conduct academic studies in areas such as dry form consumption, sucrose esters, phenolic structure, phytoremediation (soil and wastewater treatment). Besides to revitalizing unsuitable soil types and respirable atmosphere, the husks which are surrounding the tomatillos are quite successful in elimanting heavy metals ( $\mathrm{Ni}, \mathrm{Cd}, \mathrm{Cu}$ etc.) in contaminated water. Tomatillo plants were used to remove soil and water pollution, like a bio absorber of metals such as iron and manganese, which give a metallic taste to the water. By this way, harm to the environment and human health can be reduced by growing tomatillo in the contaminated soil of the industrial area [19-21].

Finally, the use of tomatillo as a food additive to the food industry as a protective component to increase the consumption of more reliable and natural products can be targeted.

\section{Conclusion}

Tomatillo adapt to the climatic conditions in Turkey will increase crop efficieny and tomatillo cultivation in Turkey. More than one harvest in a year may bring economic vitality to agriculture. In addition tomatillo facilitate to find fresh products in markets. Also high mineral content (like $\mathrm{Mg}, \mathrm{K}$ and $\mathrm{Fe}$ etc.) and involve superior pectin can thought to be suitable for use in food processes such as jam and marmelade. Furthermore tomatillo has a similar antiinflammatory effects such as aspirin, ibuprofen and naproxen medicines in the pharmaceutical industry. Medical researches of tomatillo extractions in cancer prevention empirical studies might bring out that beneficial in promoting and sustaining the consumption of this plant itself and its products.

\section{References}

1. Kindscher K, Long Q, Corbett S, Bosnak K, Loring H, et al. (2012) The ethnobotany and ethnopharmacology of wild tomatillos, Physalis longifolia Nutt. and related Physalis species: A review. Econ Bot 66 (3): 298-310.

2. Bermejo JEH, Leon J (1992) Negleted crops 1492 from a different perspective. Botanical Garden of Cordoba (Spain 9 Etnobotanica 92 Programme Andalusia. 117-122

3. Valdivia-Mares LE, Zaragoza FAR, Sanchez Gonzalez JJ (2016) Phenology agronomic and nutritionaş potential of three wild husk tomato (Physalis, Solanaceae) species. Scientia Horticulturae 200: 8394.

4. Kervankıran İ (2011) Afyonkarahisar ilinde alternatif tarım çalışmalarına birörnek: Jeotermal seracılık. Marmara Coğrafya Dergisi 24: 383-402.

5. Bayer Crop Science (2006) The Bayer crop science magazine for modern agriculture.

6. El Sheikha AF, Durand N, Sarter S, Okullo JBL, Montet D (2012) Study of the microbial discrimination of fruits by PCR-DGGE: application to the determination of the geographical origin of Physalis fruits from Colombia, Egypt, Uganda and Madagascar. Food Control 24: 57-63

7. Ostrzyca J, Horbowicz M, Dobrzanski W, Jankiewicz LS, Borkowski J (1988) Nutritive value of tomatillo fruit (Physalis ixocarpa Brot.) Acta Societatis Botanicorum Poloniae 57(4): 507-521.

8. McGorrin RJ, Gimelfarb L (1998) Comparison of flavor components in fresh and cooked tomatillo with red plum tomato. Food Flavors Formation Analysis and Packing Influences 295-313.

9. Martinez-Cayuela M (1995) Oxygen free radicals and human diease. Biochimiea 77(3): 147-161.

10. Pereira RB, Singh H, Munro PA, Luckman MS (2003) Sensory and instrumental textural characteristics of acid milk gels. International Dairy Journal 13 (8): 655-667.

11. Sousa G, Nielsen HL, Armagan I, Larsen J, Sørensen SO (2015) The impact of rhamnogalacturonan I side chain monosaccharides on the rheological properties of citrus pectin. Food Hydrocolloids 47: 130139.

12. Morales-Contreras BE, Rosas-Floores W, Contreras-Esquivel JC, Wicker L, Morales-Castro J (2018) Pectin from husk tomato (Physalis ixocarpa Brot): Rheological behavior at different extraction conditions. Carbohydrate Polymers 179: 282-289. 
13. Zaragoza FAR, Valdivia-Mares LE, Gonzalez JJS, Vargas-Ponce 0 (2016) Phenology, agronomic and nutritional potential of three wild husk tomato species (Physalis, Solanaceae) from Mexico. Scientia Horticulturae 200: 83-94.

14. Fiedorow ZG, Jankiewicz LS (1993) Virus dieases of tomatillo plant (Physalis ixocarpa Brot) in Poland. Phytopathol Polonica 5: 31-38

15. Dyki B, Jankiewicz LS, Staniaszek M (1998) Anatomical structure and surface micromorphology of tomatillo leaf and flower (Physalis ixocarpa Brot, Solanaceae). Acta Societatis Botanicorum Poloniae 67 (2): 181-191.

16. Zhang CR, Khan W, Bakht J, Nair MG (2016) New antiinflammatory sucrose esters in the natural sticky coating of tomatillo (Physalis philadelphica) an important culinary fruit. Food Chemistry 196: 726732

17. Smith and Jimenez, (1999) Tomatillo production in California Vegetable Research and Information Center, Division of Agriculture and Natural Resources Publication 7246.
18. Masabni J, King S, Taylo C (2013) Easy Gardening: Tomatillos. Texas Agrilife Extension 1-3.

19. Cooper MR, Catauro P, Perchonok M (2012) Development and evaluation of bioregenerative menus for Mars habitat missions. Acta Astronautica 81(2): 555-562.

20. Garcia-Mendieta A, Olguin MT, Solache-Rios M (2012) Biosorption properties of green tomato husk (Physalis philadephica Lam) for iron, manganese and iron-manganase from aqueous systems. Desallination 284: 167-174.

21. Eren A (2014) Andızotu, fenerotu ve sığırkuyruğu bitkilerinin ağır metallerce kirlenmiș toprakların temizlenmesinde kullanım olanaklarının belirlenmesi. Mustafa Kemal Üniversitesi Fen Bilimleri Enstitüsü Tarla Bitkileri Anabilim Dalı, Doktora Tezi (Danışman: Prof. Dr. Ersin Can).
This work is licensed under Creative Commons Attribution 4.0 License DOI: 10.19080/ARTOAJ.2018.14.555926 